\title{
The OSCE and Peacekeeping: Track Record and Outlook
}

\author{
Fred Tanner"
}

\section{Abstract}

The Special Monitoring Mission to Ukraine (SMM) is one of the OSCE's few success stories in recent years. This civilian mission has been uniquely able to operate as a quasi-peacekeeping force in high-risk areas of Donbas, monitoring ceasefire compliance and facilitating dialogue and humanitarian action in support of those living in the conflict zone. In the history of the OSCE, there has been only one other ceasefire monitoring mission: the Kosovo Verification Mission (KVM). This contribution to OSCE Insights considers the track record of OSCE peace operations, with special attention to the abovementioned missions. All OSCE peace operations to date have been civilian missions, and this paper considers military OSCE mission to be unfeasible also for the future. The paper provides lessons learned and recommendations for future missions by the OSCE and other organizations operating in high-risk environments.

Keywords

OSCE, peace operations, Kosovo Verification Mission, Special Monitoring Mission to Ukraine, lessons learned and best practices.

To cite this publication: Fred Tanner, The OSCE and Peacekeeping: Track Record and Outlook, IFSH (ed.), OSCE Insights 4/2021 (Baden-Baden: Nomos, 2022), https://doi.org/10.5771/978374 8911456-04

\section{Introduction}

This paper deals with lessons learned from civilian OSCE peace operations in high-risk areas. ${ }^{1}$ Such missions are an integral part of international efforts in conflict prevention, crisis management, and peacebuilding activities. According to the

\section{* Fred Tanner}

The Graduate Institute, Centre on Conflict, Development \& Peacebuilding, Geneva Associate Fellow, Geneva Centre for Security Policy (GCSP)

fred.tanner@graduateinstitute.ch
Stockholm International Peace Research Institute, sixty-two peace operations were deployed worldwide in 2020, with the UN accounting for twenty-five and the OSCE for sixteen. ${ }^{2}$ On the surface, it might seem that a multidimensional UN peacekeeping mission in Somalia has little in common with an OSCE operation in the Western Balkans or Central Asia. In fact, however, most OSCE field missions would qualify as what the UN High-Level Independent Panel on Peace Operations refers to as a "peace operation", although OSCE peace operations do not include "robust" elements such 
as the protection of civilians. OSCE missions with formed police or armed units remain unlikely, even though they have been discussed ever since field missions were authorized by the Helsinki Document in $1992 .^{3}$

Options for military peacekeeping by the OSCE have been worked out only once, by the High-Level Planning Group (HLPG) as part of the OSCE-led Minsk mediation platform on NagornoKarabakh launched in 1995. Anticipating a peace agreement between Armenia and Azerbaijan, the HLPG developed four options, the most robust of which involved the deployment of armed contingents with infantry battalions of up to almost 5,000 troops. This peacekeeping track came to an abrupt end in late 2020, however, when Azerbaijan regained its territories by force and Russia sent a national peacekeeping contingent to the region.

\section{OSCE experience in peace operations}

What are the political and operational lessons learned from OSCE missions, and how can they improve both the impact and the political and operational viability of future peace missions? In the past twenty-five years, the OSCE has mandated several field operations to include police- or military-related components, albeit based on individual secondments rather than deploying military units. Military observers have been sent to Moldova (since 1993) and to Georgia (2008), civilian border monitors were installed along the Georgian border with the Russian Federation (1999-2005), and civilian po- lice advisors were part of the Community Security Initiative in Kyrgyzstan (20102015).

On the peacebuilding side, police training and strengthening, including assisting police institutions, were conducted by the OSCE Mission to Croatia and within the framework of the Community Security Initiative in Kyrgyzstan. The Mission to Skopje, with its Public Safety and Community Outreach Department, remains dedicated to police training, monitoring, and reform, in addition to police support in the fight against illicit arms trafficking and organized crime. ${ }^{4}$

Whereas OSCE field operations in Central Asia and the Western Balkans have focused primarily on strengthening resilience and good governance, the OSCE's missions in Bosnia and Herzegovina, Kosovo, and North Macedonia were tasked with supporting the implementation of peace agreements and/or UN resolutions aimed at conflict prevention and conflict resolution.

\section{OSCE ceasefire monitoring missions}

To date, only two OSCE missions can be compared to military-type peacekeeping operations: the Kosovo Verification Mission (KVM) and the Special Monitoring Mission to Ukraine (SMM). Both civilian ceasefire monitoring missions began in situations of relative calm, but ended up in kinetic environments where there was no peace to keep. The KVM's deployment to Yugoslavia occurred during the unravelling Kosovo crisis in 1998, with atrocities on the ground and threats by 
the US and NATO to use force against the Milosevic regime. The mandate for the KVM, negotiated without OSCE involvement and handed down by the Holbrooke-Milosevic agreement, required both sides to end the atrocities, withdraw armed forces from Kosovo, and abide by a ceasefire. The KVM was supposed to be about twice the size of the current SMM, but it was unable to augment its presence quickly enough to deal with rising security threats. In March 1999, six months after its initial deployment, it relocated to the neighbouring Former Yugoslav Republic of Macedonia (FYROM) for security reasons before being terminated.

The SMM was conceived in early 2014 as a preventive deployment operation aimed at de-escalation, trust-building, and dialogue facilitation throughout Ukraine. Within weeks, the mission found itself at the frontline of an armed conflict and had to adjust to new security conditions and new ceasefire monitoring tasks, based on the Minsk agreements. The SMM has since become an important crisis management instrument of the OSCE in Ukraine, covering a broad spectrum of activities.

In the following, I look at six essential features of these two missions, with an emphasis on the SMM, in order to identify lessons learned and best practices and generate recommendations for future OSCE missions as well as other regional and international missions under a UN mandate.

\section{Mission mandate}

The mandate of the KVM was negotiated without OSCE participation. This led to a discrepancy between the political process and operational planning and strategic oversight. The mission had an overwhelmingly broad agenda, including ceasefire monitoring, investigating violations, supporting the return of displaced persons, monitoring governance implementation, and supervising elections. This, combined with organizational shortcomings, led to inability on the part of the KVM leadership to establish a coherent implementation plan. ${ }^{5}$

By contrast, the SMM mandate was drafted by the OSCE Chair together with the other participating States during the Maidan crisis in 2014, achieving consensus, despite a highly charged political climate, on a mandate that has continued to sustain support to this day. ${ }^{6}$ The breadth of the mandate allowed for flexibility with regard to the mission's geographical scope, which was essential given Russia's illegal annexation of Crimea. The mandate is not without shortcomings, however. In certain domains, such as dialogue promotion, more prescriptive language could have helped to create greater synergy with other ongoing OSCE initiatives in Ukraine. The omission of any reference to integrating a gender perspective into mission activities represents a further shortcoming.

The flexibility of the SMM mandate allowed for responsiveness to conflict dynamics and new realities on the ground. Although it has remained unchanged since 2014, the mission has since been 
assigned additional tasks, some handed down by the Trilateral Contact Group (TCG) and some by the Normandy format. As the OSCE report "A Peaceful Presence" shows, the mission-planning capacities of the OSCE and the SMM are still very limited. Short-term urgencies risk leading to mere stopgaps, and there is little capacity or space to engage in long-term planning and strategizing. ${ }^{7}$

\section{Deployment settings}

Both the KVM and the SMM faced the paradox of having to deal with military challenges within civilian peace missions. ${ }^{8}$ During the short planning phase of the KVM in 1998, the OSCE executive stuctures were unable to provide clear guidance on how to implement the mandate. Moreover, the recruitment process (primarily for secondments with ceasefire verification expertise and policing) was slow, despite a UN appeal to all OSCE participating States. ${ }^{9}$ After three months, 700 monitors were in place, and by March of 1999, when the mission ended because of security concerns, this number had increased to 1,400 . From the outset, KVM lacked the necessary institutional back-up for the accelerated "force generation" and robust duty of care regime required by such an ambitious field operation in an active conflict environment.

By contrast, the OSCE's SMM was able to rely from the start on the institutional support of the OSCE Secretariat, and in particular on the Conflict Prevention Centre (CPC), which helped it to continuously adapt its operations, staffing, and asset procurement. Thanks to the lessons learned from the KVM mission and the empowerment provided by Ministerial Council Decision No. 3/11 on the conflict cycle, ${ }^{10}$ the $S M M$ was able to rely on a pre-existing:

- operational framework for crisis response and personnel;

- rapid deployment roster; and

- virtual pool of equipment. ${ }^{11}$

\section{Impartiality in reporting and conduct}

Impartiality is a key requirement for any peace mission, together with consensus and the non-use of force. In the late 1990s, the OSCE was caught in an iterative power struggle between the Milosevic regime and a forceful US diplomacy posture supported by the UN Security Council and NATO. The agreement to deploy an OSCE mission was part of a deal that included enabling a NATO air surveillance mission over Yugoslavia. Furthermore, the security of the KVM depended on a NATO extraction force established in the neighbouring FYROM. ${ }^{12}$ With the nomination of the US diplomat William Walker as Head of Mission (HoM), the OSCE was unable to maintain its impartial and neutral character, as the US was clearly positioned as an opponent to the Milosevic regime. This was made dramatically clear when the HoM was declared persona non grata by the host state. ${ }^{13}$

The SMM, by contrast, is not a child of brinkmanship diplomacy and has been able to retain its impartiality. Although it 
has sometimes been criticized, the SMM has, contrary to UN practice, pursued a "no attribution policy", i.e., "reporting the facts without attributing blame and balancing hard security issues with the humanitarian, political and socio-economic consequences of the conflict". ${ }^{14}$ There have nevertheless been persistent efforts to influence the mission politically, including by national delegations to the OSCE, whether regarding duty of care issues or attributions of ceasefire violations.

\section{Use of advanced technology as a force multiplier}

Whereas the KVM was a "low-tech" mission, under political pressure by the Chairpersonship the SMM acquired advanced technology, including cameras, satellite imagery, acoustic sensors, and unarmed aerial vehicles (UAVs) to augment the information gathered by its ground patrol teams. The use of such technology by the SMM was sanctioned by the Minsk ceasefire agreements. The OSCE did not possess any internal expertise in the procurement or use of UAVs, however, and finally engaged in a turnkey arrangement with a private company to outsource technical services and expertise under the direct control of the SMM. ${ }^{15}$

The use of UAVs became a "force multiplier" for the mission as they could take on tasks that would otherwise be carried out by patrol teams in dangerous or denied areas. Remote monitoring also played an important role during the
COVID-19 pandemic, as it could hedge attempts to weaponize the pandemic through lockdowns, denial of access, and "border" closures.

Operating UAVs in active conflict zones is risky and expensive, with many being jammed and fired upon in flagrant violation of the Minsk provisions. From the first UAV flight in October 2014 to 31 March 2019, the SMM lost thirty-nine UAVs. Of these, 67 per cent were lost in the non-government-controlled areas, 31 per cent in the government-controlled area, and 2 per cent along the contact line. ${ }^{16}$

With the increasing use of advanced technology, challenges have emerged regarding how to process and utilize the data flow. The SMM found itself ill equipped to process large amounts of multi-sourced information. In addition, monitors' access to satellite and UAV imagery often took too long to be effective in patrol planning and implementation. A new information management system had to be established for data fusion and in preparation for decision-making, planning, and public reporting. ${ }^{17}$

\section{Legal personality and duty of care}

The OSCE's lack of legal personality represents a serious handicap for any OSCE field mission. The SMM was unable to build up its field presence as planned until a memorandum of understanding with the host government was secured several weeks after the mission was launched. ${ }^{18}$ Even worse, during the first weeks without legal protection in Ukraine, the OSCE was accountable 
for any injury caused. During this period, eight monitors were taken hostage by a band of Cossacks, which prompted the question of who was liable should injury occur: the Head of Mission, the Secretary General, the Chairpersonship, the seconding participating States? Such duty of carerelated questions have not been settled to date. ${ }^{19}$ Another key deficiency of the SMM is its lack of force protection and its dependency on security guarantees by the belligerents. Unlike the KVM, the SMM lacks a dedicated military extraction force. A complex conflict environment requires that preparations for duty of care arrangements go hand in hand with mission planning. Unfortunately, this was not the case for either of the OSCE's peacekeeping missions. In the case of the KVM, for example, appeals by the OSCE for mobile medical care, including medical and armoured vehicles, went unanswered until months after the mission was deployed. ${ }^{20}$

\section{Partnerships for joint or hybrid missions}

To date, no OSCE missions have been conducted in tandem with missions of other organizations. The 1999 Istanbul Charter for European Security enabled the OSCE to work jointly with other regional and international organizations, including in the peacekeeping domain. ${ }^{21}$ A proposal for a hybrid or "expanded" SMM emerged in 2014 when Germany, France, Italy, and the Russian Federation each offered UAVs, together with military support units, to the mission. These national offers included a military protection force. The inclusion of national mil- itary units in the SMM would have potentially undermined the civilian nature and impartiality of the mission, however. Furthermore, it would have required an additional Permanent Council decision and a bilateral status of forces agreement with Ukraine. ${ }^{22}$

Another proposal for a hybrid operation, again in Ukraine, came from Russia in 2017 when it submitted a draft UN Security Council Resolution proposing a lightly armed UN peacekeeping force to protect the SMM along the line of separation..$^{23}$ Ukraine rejected the option of a hybrid UN-OSCE mission and in turn proposed a robust Chapter VII enforcement operation at the 2017 UN General Assembly, an option that would have made the SMM redundant. ${ }^{24}$ Both proposals gained little traction and were shelved.

\section{How to build on the track record of the SMM}

The SMM has proven capable of following a steep learning curve since its deployment in 2014. Despite constant violations of the ceasefire, denial of access, and the COVID-19 pandemic, it has continued to work on both sides of the line of contact, albeit sometimes with serious constraints. Over the years, a wider community of scholars and practitioners has begun to examine how the mission was conducted and to identify lessons learned..$^{25}$

Given the encouraging example of the SMM, it is possible that the participating States would agree to a similar mission 
elsewhere, should changes to regional security and politics require it. The most obvious choice would be an operation in the Nagorno-Karabakh region. It is true that the Minsk Group Co-chairs and the HLPG have been side-lined by the deployment of a Russian peacekeeping force. Nevertheless, as one expert group argues, there may still be a need for a multinational OSCE peacekeeping force, "as over time Moscow may not want to bear the costs and burdens it has now incurred alone". ${ }^{26}$ Depending on political developments, and as part of a broader architecture, a possible settlement could call for a comprehensive OSCE civilian peace mission to monitor compliance with commitments and support peacebuilding activities.

\section{Conclusion and recommendations}

Civilian operations have a light footprint, which is an asset compared with classic UN military peacekeeping operations. As non-coercive and facilitative missions, they are more likely to achieve political consensus for their mandate, be acceptable to the host state, and remain impartial. The key is to achieve and retain joint political-operational ownership of the mandate while remaining able to "harden" the mission should it operate in a zone of armed conflict. ${ }^{27}$

The mandate and additional tasks of the SMM go well beyond ceasefire monitoring and include monitoring and reporting on human rights abuses and environmental security while offering good offices and mediation support. ${ }^{28}$ The
OSCE's commitment to this comprehensive approach has been an advantage. Today's peace missions are increasingly required to deal with issues related to instability, fragility, and governance in all phases of the conflict cycle.

As current geopolitical trends indicate, peace operations as instruments for conflict prevention and crisis management will remain in demand for years to come. In planning such an operation (or indeed other possible OSCE missions), and drawing on the lessons learned and best practices of previous missions (especially the SMM), the following recommendations should be considered:

- Develop a flexible mission mandate. Mission mandates should only be prescriptive in areas where guidance is needed. A good field mission mandate will facilitate proper planning and strategy development by mission leadership. Compromise and consensus for a mandate could also be achieved through interpretative statements, as was the case for the SMM. An explicit reference to gender parity and gender perspectives should be an integral part of the mandate.

- Ensure solid institutional support for mission deployment. The issue of the KVM's inability to rapidly deploy experts with the right skills has highlighted the importance of having solid institutional support for mission deployment. However, rapid secondment of civilian personnel with qualified military expertise depends more on seconding states than on the OSCE. Rapid deployment rosters and 
new Secretariat-wide internal standard operating procedures (SOPs) are helpful for effective action in urgent response situations. ${ }^{29}$ A strengthened planning team in the Secretariat can achieve improved preparedness and mission design, not just for a possible mission in Nagorno-Karabakh but for other missions as well. It is worth exploring the extent to which the HLPG could be more closely associated with the work of the CPC, thereby enabling broader planning capacities within the Secretariat across the entire mission spectrum.

- Preserve impartiality. The nationality of the HoM matters, and reporting guidance should include a "no attribution" SOP. The OSCE should develop guidance for dealing with nonrecognized actors, based on the 1993 OSCE document Stabilizing Measures for Localized Crisis Situations. ${ }^{30}$

- Make use of advanced technology. Technical monitoring has become a hallmark of the SMM. Remote monitoring allows for the avoidance of hazardous terrain and unfriendly checkpoints. Combined with enhanced data processing and operational planning, it can make missions more effective and more secure. Data processing platforms and related expertise should be made available from the outset. OSCE field missions can learn from the SMM's experience by using advanced technology for other tasks, such as natural disaster risk management.

- Duty of care should go hand in hand with mission planning. For any civil- ian field mission operating in a highrisk environment, a duty of care strategy and proper oversight measures should be in place from the outset.

- Be aware of the risks of joint missions. Missions conducted in tandem with other organizations are feasible but politically difficult. Hybrid arrangements with police or military contingents would stretch OSCE planning capacities and potentially jeopardize OSCE impartiality. Furthermore, a UN Security Council Resolution would be a prerequisite.

- Maintain a close interface between the political process and operations. The fate of the KVM has taught that it is imperative for the leadership of field operations to have access to the political process. This prevents the fragmentation of responsibilities, always a risk in complex operations. In the case of the SMM, this issue was addressed by granting the SMM Chief Monitor a seat at the table in the Minsk process (as coordinator of the TCG's Security Working Group).

- Raise awareness of the advantages of the OSCE and its operations. In view of its wealth of experience, the OSCE should invest more in both its institutional learning process and outreach activities. It is important for participating States and international organizations to develop more trust and confidence in the OSCE's ability to manage crises and conduct peace operations, even in high-risk regions. 


\section{Notes}

The term "peace operations" is used to cover the notions of peacekeeping, peace missions, special political missions, and field operations. In the literature, peacekeeping and peace missions are often used interchangeably.

"Multilateral peace operations", Stockholm International Peace Research Institute, 2020, https://www.sipri.org/sites/def ault/files/2020-06/mpo20_fill.pdf

Chapter III of the Helsinki Document (1992) continues to be the main regulative framework for possible OSCE activities in the field of peacekeeping. See OSCE, Helsinki Document 1992: The Challenges of Change, 10 July 1992, https://www.osce.org/mc/39530

For more information on all current OSCE field operations, see OSCE, Survey of OSCE Field Operations, SEC.GAL/111/20/Corr.1*, 26 August 2020, https://www.osce.org/secretariat/ 74783

Alex J. Bellamy/Stuart Griffin, "OSCE Peacekeeping: Lessons from the Kosovo Verification Mission", in: European Security 1/2002, 1-26, p. 22.

The mission was at the outset renewed six months at a time, thereafter extension was and continues to be on an annual basis.

OSCE, A peaceful presence - the first five years of the OSCE Special Monitoring Mission to Ukraine, 29 June 2021, p. 53, https://www.osce.org/secretariat/491220 and international organizations to make available personnel to the OSCE Verification Mission in Kosovo"; see UNSC, Resolution 1203 (1998), S/RES/1203 (1998), 24 October 1998, https://digitallibrary.un .org/record/262334?ln=en

10 OSCE Ministerial Council Decision No. 3/11 on Elements of the Conflict Cycle, 7 December 2011, https://www.osce.org/fil es/f/documents/6/b/86621.pdf

11 Michael Raith, Addressing the Conflict Cycle: The OSCE's Evolving Toolbox, IFSH (ed.), OSCE Insights 3/2020 (Baden-Baden: Nomos, 2020), at: https:// doi.org/10.5771/9783748922339-03, p. 48.

12 NATO Press Statement, (98)139, 5 December 1998, https://www.nato.int/doc u/pr/1998/p98-139e.htm

13 OSCE Chairmanship, "Head of Kosovo Verification Mission declared 'persona non grata", OSCE, 19 January 1999, https://www.osce.org/cio/52376

14 OSCE, cited above (Note 7), p. 67.

15 It included a package agreement with a private company that, at the outset, provided two ground control stations, four long-range UAVs, six operators, and three maintenance staff; see OSCE, cited above (Note 7), p. 49.

16 OSCE, cited above (Note 7), p. 50.

17 The implementation of the so-called Enterprise Geographic Information System remains a protracted issue.

18 Not having legal status made the procurement process and importations to Ukraine cumbersome. It also prevented the mission from opening bank accounts, concluding contracts, and importing key equipment. See OSCE, cited above (Note 7), p. 20.

19 Since the first exposures of the SMM monitors to threats of injury, much work has been done to address duty of care issues in OSCE missions; see Maarten Merkelbach, Voluntary guideline on the duty of care to 
seconded civilian personnel, Swiss Federal Department of Foreign Affairs, Stabilisation Unit and Center for International Peace Operations, 2017, https://www.eda. admin.ch/dam/eda/en/documents/aussen politik/menschenrechte-menschliche-sich erheit/Voluntary_Guidelines_on_the_Du ty_of_Care_to_Seconded_Civilian_Perso nnel_Final_170420.pdf

20 Larissa Daria Meier, "A role for OSCE peacekeeping? From the 1992 Helsinki Guidelines to the Special Monitoring Mission to Ukraine", CORE Working Paper 27, 2015, p. 33, https://ifsh.de/file-CO RE/documents/Working_Papers/CORE_ WP27.pdf

21 OSCE, Istanbul Document 1999 (Charter for European Security and Istanbul Summit Declaration), PCOEW389, 1999, https://www.osce.org/mc/39569

22 Germany, for instance, offered to send a contingent with a LUNA reconnaissance drone platoon. With logistics, medical, and other elements, the contingent would have been composed of more than 200 armed soldiers.

23 See International Crisis Group, "Can peacekeepers break the deadlock in Ukraine?”, Europe Report N²46, 15 December 2017, p. 2, https://d2071andvip0 wj.cloudfront.net/246-can-peacekeepers-b reak-the-deadlock-in-ukraine.pdf

24 Fred Tanner, "Sustaining civilian missions in conflict zones: The case of the OSCE Special Monitoring Mission to Ukraine", swisspeace, Policy Brief 03, 2018, p. 2, https://www.swisspeace.ch/a
ssets/publications/downloads/Policy-Brief s/6656f90042/Sustaining-Civilian-Mission s-in-Conflict-Zones-Policy-Brief-18-swissp eace-fred_tanner.pdf

25 See, for example, Walter Kemp, "Civilians in a War Zone: The OSCE in Eastern Ukraine", in: IFSH (ed.), OSCE Yearbook 2017, Baden-Baden: Nomos, 2018, 113-123; André Härtel/Anton Pisarenko/ Andreas Umland, "The OSCE's Special Monitoring Mission to Ukraine: The SMM's Work in the Donbas and Its Ukrainian Critique in 2014-2019”, in: Security and Human Rights, June/2021, 1-34; OSCE, cited above (Note 7).

26 Global Europe Program Working Group on the Future of the OSCE, Uncommon cause: The future of the OSCE, The Wilson Center, February 2021, p. 7, https:// www.wilsoncenter.org/sites/default/files /media/uploads/documents/Uncommon Cause - The Future of the OSCE v2.pdf.

27 Hardening measures include giving priority to military skills in recruitment, dedicated training, medevac capacities, armed vehicles with GPS, flak jacket and helmet, mission-wide satellite communication, etc. See Larissa Daria Meier, cited above (Note 20), p. 46.

28 OSCE, cited above (Note 7), p. 17.

29 Raith, cited above (Note 11), p. 48.

30 OSCE, Stabilizing Measures for Localized Crisis Situations, DOC.FSC/2/96, 25 November 1993, https://www.osce.org/fs c/41316 